INTERDISCIPLINARY JOURNAL OF THE ACADEMIA EUROPAEA

\title{
Featuring
}

\section{Climatic Changes}

by Hans Oeschger

and

New Perspectives on Ancient Science by Geoffrey Lloyd

\section{Special Focus Section}

\section{Structure of the Universe}



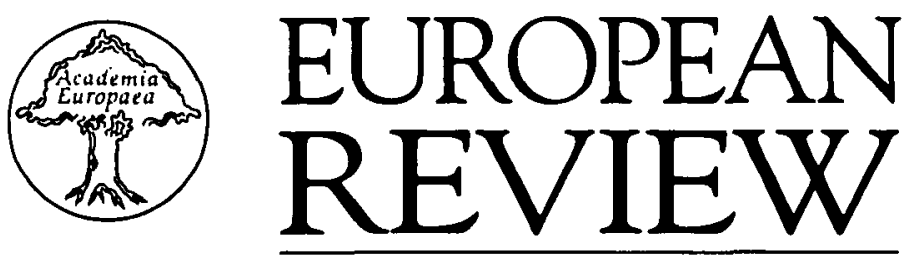

EDITOR-IN-CHIEF

Arnold Burgen

Department of Pharmacology

Tennis Court Road

University of Cambridge

Cambridge, CB2 10J

UK

\section{ASSOCIATE EDITORS}

\section{Robert Cahn}

Cambridge University, Department of Material Sciences and Metallurgy, Pembroke Street,

Cambridge, CB2 10Z, UK

Kjell Härnqvist

Sveagatan 9, S413 14 Gothenburg, Sweden

Alexis Jacquemin

16. Avenue Ptolémée, 1180 Brussels, Belgium

Henri Korn

Institut Pasteur, Laboratoire de Neurobiologie Cellulaire, Inserm U.261, 25 rue du Dr Roux, 75015 Paris, France

\section{Ernst Mestmäcker}

Max-Planck-Institute fur Auslandisches und Internationales Privatrecht, Mittelweg 187. 2000 Hamburg 13, Germany

Henk Wesseling

Institute for the History of European Expansion, PO Box No 9515, 2300 RA Leiden,

The Netherlands

\section{Barbara Wright}

Trinity College, Department of French, Arts Building, Dublin, Ireland

\section{AIMS AND SCOPE}

The European Review is an Interdisciplinary Review Journal of the Academia Europaea. The contents reflect the broad range of disciplines included within the Academia, as well as its comprehensive European membership. The review will thus include articles covering a wide range of topics written so as to make them accessible to readers from other disciplines. Each issue will include a special section focused on a particular topic. The articles will be by authors mostly located in Europe and some will relate to specifically European questions.

Authorship is in no way restricted to members of the Academia Europaea and the Editors welcome submissions.

\section{ACADEMIA EUROPAEA}

The Academia Europaea was established in 1988 to bring together scholars from across Europe, East and West, of all academic disciplines. It has already proved to be an admirable medium for tackling problems on a Europe wide basis and especially on an interdisciplinary basis-bringing together scholars from disciplines that would be unlikely to meet otherwise. It organizes symposia at annual meetings which move around Europe and which have covered subjects like the Rights of Minority Groups, the Image of Science, the Study of the Human Genome, Population Migration, and the Search for Meaning in Contemporary Life. It has also established study groups, the first of which has published its findings in a book on 'Schooling in Contemporary European Society'. Other studies are in progress on Problems of Youth in a Changing Europe, Energy Forecasting, Higher Education, Teaching Science in Schools, Social Aspects of Science Policy, and the Idea of Progress.

It can be seen that the Academia Europaea has a wide perspective and this is reflected in this Review.

The Academia is an independent organization based in London.

Advertising: For details contact-

U.K. and Europe: Michael J. Levermore, Advertisement Sales, John Wiley \& Sons Lid, Baffins Lane, Chichester, Sussex PO19 1UD, England (Telephone 0243 770350).

North America: Dora Castiblanco-Advertisement Supervisor, John Wiley \& Sons Inc., 605 Third Avenue, NY 10158 (Telephone 2128506289 , telex 12-7063, fax 2128506088 ).

To subscribe: European Review: the Interdisciplinary Journal of the Acodemia Europaea (ISSN 1062-7987) is published quarterly by John Wiley \& Sons Ltd, Baffins Lane, Chichester, Sussex, England. 1994 subscription prices: US\$195.00, bona fide personal subscriptions to UK f55.00; elsewhere US\$85.00; Academia Europaea members subscriptions, UK $\{35.00$; elsewhere US $\$ 60.00$. Air freight and mailing in the U.S.A. by Publications Expediting Services, Inc., 200 Meacham Avenue, Elmont, NY 11003. Orders should be addressed to: Subscriptions Department, John Wiley \& Sons Ltd, Baffins Lane, Chichester, Sussex P019 1UD, England. Copyright (C) 1994 by John Wiley \& Sons Ltd. Typeset in the U.K. by KEYWORD Publishing Services Ltd., London. Printed and bound in Great Britain by BPCC Wheatons, Exeter. Printed on acid-free paper.

U.S.A. POSTMASTER: Send address changes to European Review: the Interdisciplinary Journal of the Academia Europaea c/o Publications Expediting Services Inc., 200 Meacham Avenue. Elmont, NY 11003. 


\section{Contents}

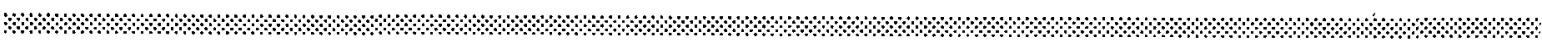

VOLUME 2 NUMBER 2

New Perspectives on Ancient Science

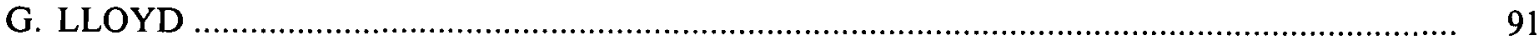

The Awareness of Global Climatic and Environmental Change

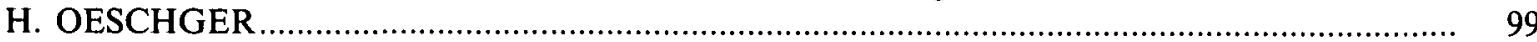

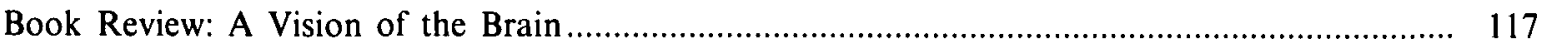

FOCUS-Structure of the Universe

Introduction

A. BURGEN

Scientific Accounts of the Universe from Antiquity to Kepler

O. PEDERSEN

The Explosion of the Horizons

J.-C. PECKER

The Emergence of Complex Structure in Astronomy

B. GUSTAFSSON

Cosmology: Evidence for a 'Big Bang'

M. J. REES

Observations which Contradict the Hypothesis of a Big Bang Universe

H. ARP

Discussion

Indexed or abstracted by 'GEOBASE', 'Geographical Abstracts: Human Geography'

EURREK 2(2) 91-176(1994)

ISSN 1062-7987 